\title{
PEMBUATAN PERANGKAT PENILAIAN KINERJA KARYAWAN BERPOLA 360 DERAJAT PADA KOPERASI WARGA POLBAN BANDUNG
}

\author{
Hennidah Karnawati ${ }^{1}$, Koernia Purwihartuti ${ }^{1}$, Marwansyah ${ }^{1}$, Tiafahmi Angestiwi ${ }^{1}$, \\ Kristianingsih ${ }^{2}$ \\ ${ }^{1}$ Jurusan Administrasi Niaga, Politeknik Negeri Bandung \\ ${ }^{2}$ Jurusan Akuntansi, Politeknik Negeri Bandung \\ Email: tia.fahmi@polban.ac.id
}

\begin{abstract}
Abstrak
Perkembangan dan perluasan unit bisnis koperasi menuntut pengelolaan yang lebih serius karena pelayanan prima menjadi unsur yang dituntut oleh pelanggan. Pada penyedia jasa seperti koperasi, karyawan merupakan unsur terpenting dalam pelayanan. Karyawan akan termotivasi untuk bekerja seandainya merasa dihargai oleh koperasi. Salah satu faktor penghargaan adalah dengan pemberian nilai yang sesuai dengan kinerjanya. Permasalahan yang ada di KWP POLBAN adalah penilaian kinerja karyawan masih dinilai per unit layanan belum per individu karena belum ada perangkat penilaiannya. Ini kurang memotivasi karyawan untuk bekerja maksimal. Tujuan program kemitraan ini adalah untuk membuat perangkat penilaian kinerja berpola 3600. Pola penilaian 3600 merupakan penilaian yang dilakukan oleh semua unsur yang berhubungan dengan karyawan, misalnya atasan langsung, rekan kerja, dan pelanggan. Program ini merekomendasikan penggunaan instrumen penilaian kinerja karyawan KWP dengan indikator secara keseluruhan berjumlah 30. Jumlah indikator pada keempat instrumen disesuaikan dengan penilai yang berbeda, yakni atasan, rekan setingkat, bawahan, dan pelanggan.
\end{abstract}

Kata kunci: Penilaian kinerja, penilaian 360 derajat, koperasi

\section{PENDAHULUAN}

Perkembangan koperasi secara nasional dalam 10 tahun terakhir mengalami pertumbuhan signifikan. Menurut Kementerian Koperasi dan UKM Tahun 2015 terdapat 25.741 koperasi di Jawa Barat (Pikiran Rakyat, 19 Mei 2017). Sebanyak 16.855 koperasi, aktif dan sisanya yakni 8.886 tidak aktif. Koperasi yang melakukan RAT hanya 6.697 unit. Hal tersebut karena kurangnya partisipasi para anggota dan pelayanan yang masih kurang bermutu.

Koperasi Warga Polban (selanjutnya disebut KWP) adalah salah satu koperasi aktif di Jawa Barat. Kinerja suatu organisasi dibangun oleh kinerja dari ber- 
DIFUSI

Volume 3, No.1 Januari 2020

bagai kelompok atau tim kerja dalam koperasi yang dikenal sebagai unit layanan. Selanjutnya kinerja organisasi dapat diukur menggunakan sejumlah parameter, antara lain keuangan berupa profit (keuntungan). Kinerja KWP diukur dengan menggunakan parameter keuangan dalam bentuk SHU (sisa hasil usaha). Kinerja dilihat dari masing-masing unit layanan (Tabel 1).

Kinerja setiap kelompok atau unit layanan ditentukan oleh kinerja setiap individu pegawai yang ada pada kelompok atau unit layanan tersebut. Permasalahannya adalah belum dilakukannya pengu- kuran kinerja individu karyawan. Penyebabnya adalah karena KWP belum memiliki standar penilaian kinerja. Berikut ini adalah konsekuensi dari belum dilaksanakannya penilaian kinerja karyawan.

1. Penggajian hanya berupa gaji pokok yang didasarkan pada standar penggajian yang memperhitungkan UMR, masa kerja, pendidikan, dan tunjangan keluarga.

2. Pemberian insentif (tahun buku 2016 dan 2017) didasarkan pada kinerja unit layanan dan posisi jabatan.

Tabel 1. Perolehan SHU Tiap Unit Periode 2016-2017

\begin{tabular}{lrrr}
\hline \multicolumn{1}{c}{ Uraian } & \multicolumn{3}{c}{ Tahun buku (dalam rupiah) } \\
& 2016 & \multicolumn{1}{c}{2017} & \multicolumn{1}{c}{2018} \\
\hline Sisa Hasil Usaha unit Simpan Pinjam & 649.838 .010 & 734.588 .588 & 640.582 .597 \\
Sisa Hasil Usaha unit Toko & 123.441 .027 & 182.973 .787 & 185.856 .915 \\
Sisa Hasil Usaha unit Fotokopi & 35.563 .935 & 26.221 .290 & 44.969 .187 \\
\hline
\end{tabular}

Berdasarkan data yang ada di KWP, dokumen yang sudah tersedia saat ini adalah (1) struktur organisasi dengan rincian tugas, (2) Rencana Strategis (Renstra), (3) Prosedur Operasi Baku (POB atau SOP), (4) standar, dan (5) daftar hadir harian yang sudah menggunakan perangkat mesin otomatis. Sementara itu, standar untuk melakukan penilaian kinerja karyawan belum tersedia.

Dalam tiga tahun terakhir, karyawan dianggap punya prestasi kerja yang sama karena tidak dilakukan penilaian secara objektif. Secara lebih spesifik, dalam kaitan ini ada dua isu yang dihadapi oleh KWP. Pertama, penilaian kinerja karyawan masih berbasis unit pelayanan tertentu dan belum mengacu pada kinerja individu sehingga kinerja karyawan tidak merata. Kedua, perkembangan unit bisnis yang pesat perlu diimbangi dengan pelayanan prima oleh karyawan. Dalam hubungan ini, diperlukan sistem penilaian kinerja yang dapat memotivasi dan meningkatkan kompetensi karyawan KWP.

\section{METODE}

Kompetisi secara global, khususnya di bidang bisnis dan ekonomi, organisasi bisnis membutuhkan kinerja tinggi dari karyawannya [1]. Pada saat yang sama, karyawan membutuhkan umpan balik atas kinerja mereka sebagai pedoman bagi peningkatan perilaku kerja di masa depan. Dalam konteks ini, para manajer harus menilai kinerja karyawan, yang 
DIFUSI

Volume 3, No.1 Januari 2020

menjadi dasar untuk memutuskan tahapan apa yang harus diambil berikutnya. Penilaian kinerja menjadi perangkat dasar bagi terjalinnya komunikasi dan kesepahaman antara atasan-bawahan di berbagai jenis tempat kerja [2].

Penilaian kinerja merupakan sistem formal untuk memeriksa dan mengevaluasi kinerja seseorang atau kelompok, berdasarkan standar tertentu [3]; [4]. Dalam nada yang sama, Cappelli dan Conyon [5] mendefisinikan penilaian kinerja sebagai proses yang digunakan oleh manajer untuk menilai kinerja yang terkait dengan pekerjaan para bawahannya dan mengalokasikan imbalan berdasarkan penilaian itu. Kinerja dapat diartikan sebagai "behaviour that accomplishes results" [6]. Berdasarkan pengertian tersebut, kinerja didefinisikan pencapaian seseorang berkenaan dengan tugas-tugas yang dibebankan kepadanya. Kinerja juga dapat dipandang sebagai perpaduan hasil kerja yakni apa yang harus dicapai dan kompetensi mengenai bagaimana mencapainya [1].

Sejumlah ahli mengatakan bahwa penilaian kinerja dan manajemen kinerja (performance management) adalah dua konsep yang berbeda tapi saling berhubungan [7] [4]. Mereka memandang penilaian kinerja sebagai bagian dari manajemen kinerja, tetapi menganggap manajemen kinerja sebagai konsep yang lebih luas. Penilaian kinerja adalah kunci keberhasilan manajemen kinerja [4]. Sebagian lagi berpendapat bahwa sistem manajemen kinerja adalah metode yang lebih baik dalam mengelola kinerja karyawan [8].

Menurut Noe, dkk [9] Manajemen kinerja adalah "the process through which managers ensure that employees' activities and outputs contribute to the organization's goals". Sementara itu, Mathis dan Jackson [10] mendefinisikan manajemen kinerja sebagai "series of activities designed to ensure that the organization gets the performance it needs from its employees." Dalam proses ini, manajemen perlu mengidentifikasikan kegiatan-kegiatan dan keluaran yang ingin dicapai, mengamati apakah kegiatan dan keluaran ini tercapai, dan memberikan umpan balik untuk membantu karyawan mewujudkan tujuan ini [9]. Selain itu, melalui manajemen kinerja, manajer dan karyawan dapat mengidentifikasikan masalah-masalah kinerja dan mencari solusi untuk mengatasi masalah ini.

Dalam pandangan Armstrong [6], tujuan umum manajemen kinerja yaitu agar dapat mengembangkan kapasitas manusia dalam memenuhi dan melampaui harapan serta mewujudkan potensi mereka sepenuhnya, sehingga dapat bermanfaat bagi diri mereka sendiri dan organisasi. Lebih lanjut Armstrong mengatakan bahwa manajemen kinerja memiliki peran dalam pengembangan diri. Proses tersebut terkait dengan upaya untuk memastikan tersedianya dukungan dan bimbingan yang dibutuhkan para karyawan untuk membangun dan meningkatkan kapasitas mereka.

Noe, dkk [9] mengatakan bahwa ada tiga tujuan umum manajemen kinerja, yakni tujuan yang bersifat strategis, administratif, dan pengembangan. Tujuan strategis bermakna, manajemen kinerja yang efektif membantu organisasi mewujudkan tujuan-tujuan bisnisnya. Tujuan administratif berarti bahwa organisasi dapat menggunakan sistem manajemen kinerja untuk menyediakan informasi yang 
DIFUSI

Volume 3, No.1 Januari 2020

menjadi dasar pembuatan keputusan tentang gaji, maslahat, promosi jabatan, dan sebagainya. Tujuan pengembangan berarti bahwa manajemen kinerja berfungsi sebagai dasar bagi peningkatan pengetahuan dan keterampilan karyawan.

Mondy dan Martocchio [4] membahas beberapa karakteristik yang wajib terpenuhi dalam memastikan efektivitas sistem penilaian kinerja. Karakteristik tersebut adalah (1) kriteria terkait dengan pekerjaan, (2) ekspektasi kinerja, (3) standarisasi, (4) penilai yang cakap, (5) komunikasi terbuka, (6) adanya review kinerja, dan (7) proses pengajuan keberatan. Langkah pertama, kriteria yang digunakan untuk menilai kinerja karyawan harus berkaitan dengan pekerjaan. Kedua, sebelum periode penilaian berlangsung, para manajer harus menjelaskan secara gamblang tentang kinerja yang diharapkan kepada karyawan. Ketiga, para pekerja dalam kategori pekerjaan yang sama dan berada di bawah pengawas yang sama, harus dinilai dengan menggunakan instrumen penilaian yang sama. Keempat, penilai harus memiliki wawasan yang cukup mengenai kinerja karyawan. Selain itu, untuk memastikan konsistensi dalam penilaian, maka penilai wajib mendapat pelatihan. Kelima, sistem penilaian yang baik memberikan umpan balik yang sangat dibutuhkan oleh karyawan dan secara terus menerus. Keenam, perlu disediakan waktu khusus bagi berlangsungnya diskusi tentang kinerja karyawan. Ketujuh, harus ada prosedur formal yang memberikan kesempatan pada karyawan untuk menyampaikan hasil penilaian yang dianggap tidak akurat atau tidak adil.

Penilaian kinerja dilakukan melalui serangkaian langkah sistematis. Langkah- langkah tersebut perlu direncanakan dan diimplementasikan secara cermat dan konsisten agar dapat menjamin tercapainya tujuan-tujuan penilaian kinerja. Mondy dan Martocchio [4] menjelaskan lima langkah dalam proses penilaian kinerja. Langkah pertama adalah mengidentifikasikan tujuan khusus dari penilaian kinerja, misalnya untuk promosi karyawan, mengidentifikasikan kebutuhan pelatihan, mendiagnosis masalah-masalah yang dialami karyawan. Kedua, menentukan kriteria kinerja dan mengkomunikasikannya kepada karyawan. Deskripsi jabatan yang akurat yaitu yang dihasilkan dari analisis jabatan, menjadi masukan terpenting bagi penentuan faktor-faktor penilaian yang benar-benar terkait dengan jabatan. Ketiga, memeriksa setiap tugas yang dijalankan, dengan berpedoman kepada deskripsi jabatan. Keempat, menilai kinerja, dengan memberi nilai pada setiap unsur jabatan yang diamati. Langkah akhir adalah membicarakan hasil penilaian dengan karyawan yang dinilai.

Ada sejumlah metode penilaian kinerja, yang digolongkan ke dalam metode tradisional dan metode modern [11]. Metode tradisional contohnya Ranking System dan Rating Scale. Metode yang tergolong ke dalam metode modern di antaranya 360 Degree Feedback, Management by Objective, serta Behaviorally Anchored Rating Scale (BARS) [3-4], [9].

Saat ini, penilaian $360^{\circ}$ (360-degree feedback evaluation method) menjadi metode penilaian yang semakin populer di banyak negara. Istilah $360^{\circ}$ digunakan untuk menggambarkan metode yang melibatkan masukan dari berbagai pihak dari dalam dan luar organisasi [4]. Umpan 
DIFUSI

Volume 3, No.1 Januari 2020

balik berasal dari gabungan penilaian rekan kerja, bawahan, atasan dan kadangkadang juga konsumen [6], [9].

Banyak penilai dengan sudut pandang yang berbeda-beda, sering disimpulkan bahwa penilaian $360^{\circ}$ mampu memberikan umpan balik yang lebih akurat dan bermakna [1]. Tak diragukan lagi, banyak organisasi telah memperoleh manfaat dari penggunaan metode ini, khususnya dalam konteks (atau tujuan) pengembangan manajemen--bukan semata-mata sebagai alat penilaian kinerja. Banyak perusahaan menggunakan hasil penilaian $360^{\circ}$ tidak hanya bagi tujuantujuan konvensional tapi juga bagi perencanaan suksesi, pelatihan, dan pengembangan profesional [4].

Metode pelaksanaan kegiatan pengabdian kepada mayarakat dikembangkan dengan mengacu kepada tujuan diadakannya pengabdian pada KWP yang menghasilkan empat luaran untuk pembuatan perangkat penilaian kinerja menggunakan metode 3600. Tahap-tahap pelaksanaan kegiatan dijelaskan dalam Gambar 1.

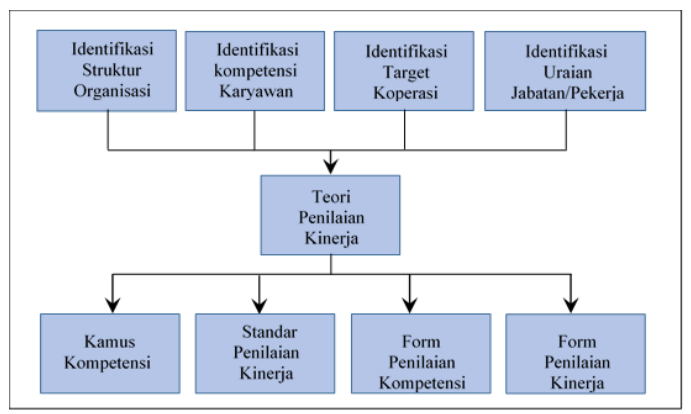

Gambar 1. Diagram Alur Metode Pelaksanaan Kegiatan Pembuatan Perangkat Penilaian Kinerja Karyawan KWP
Berdasarkan Gambar 1, tahap awal dalam membuat perangkat penilaian kinerja KWP adalah mengidentifikasi struktur organisasi, kompetensi karyawan, target koperasi, dan uraian jabatan atau pekerjaan. Hasil identifikasi tersebut digunakan sebagai dasar dalam menetapkan teori penilaian kinerja yang paling sesuai. Berdasarkan teori yang sesuai kemudian dibuatlah luaran berupa 1) kamus kompetensi 2) standar penilaian kinerja untuk melakukan monitoring dan evaluasi 3) formulir penilaian kompetensi yang akan digunakan dalam periode tertentu secara rutin dan 4) formulir penilaian kinerja.

\section{HASIL DAN PEMBAHASAN}

\section{Gambaran Umum KWP}

Koperasi Warga Polban didirikan pada tahun 1995. KWP memiliki empat unit usaha yakni simpan-pinjam, toko, fotokopi dan rental mobil. Selain itu, saat ini KWP sedang mengerjakan proyek perumahan (Batu Indah Regency) yang bersifat sementara. KWP merupakan lembaga keuangan non-bank yang berbadan hukum No.11486/BH/KWK.01/VII/1995. Visi KWP adalah "Menjadi Koperasi Kredit Unggulan di Wilayah Bandung Barat Dalam 10 Tahun Ke Depan" sementara misinya adalah (1) memberikan pelayanan yang prima pada anggota; (2) menyelenggarakan pendidikan koperasi untuk mengembangkan wawasan para anggota; (3) menyelenggarakan pendidikan kompetensi untuk meningkatkan kualitas sumber daya manusia; serta (4) 
DIFUSI

Volume 3, No.1 Januari 2020

melengkapi dan memperbaiki sarpras yang dibutuhkan untuk pengembangan sistem di koperasi.

Pada dasarnya, pengelolaan KWP dilakukan oleh tiga unsur pengelola, yakni Pengurus, Pengawas, dan Manajer (yang membawahi para koordinator unit). Pengurus terdiri atas Ketua, Wakil Ketua, Bendahara, Sekretaris dan Anggota. Saat ini, Manajer KWP membawahi empat koordinator, yakni Koordinator Unit Usaha Simpan Pinjam, Koordinator Unit Usaha Toko, Koordinator Unit Usaha Fotokopi/Percetakan, dan Koordinator Unit Usaha Perumahan (berstatus 'Proyek'). Para Pengurus dan Pengawas dipilih oleh anggota KWP melalui Rapat Anggota Tahunan (RAT). Sementara itu, manajer dan staf pelaksana diangkat oleh Pengurus.

Persyaratan menjadi anggota KWP, menurut RAT 2016 calon anggota harus memenuhi persyaratan (1) warga Polban, (2) menyerahkan kartu identitas, (3) mengisi formulir pendaftaran, (4) membayar uang untuk keperluan: biaya pangkal (Rp.50.000,), simpanan pokok (Rp. 100.000,-) yakni sekali selama menjadi anggota, serta simpanan wajib dibedakan menjadi dua macam: Rp. 100.000,- (dapat meminjam uang maksimal $\mathrm{Rp}$ 50.000.000 dengan jangka waktu 3 tahun) dan Rp.150.000,- (dapat meminjam uang maksimal Rp. 75.000.000 dengan jangka waktu 5 tahun); dan (5) mengikuti pelatihan Dasar Manajemen Koperasi.

\section{Perencanaan Penilaian Prestasi Berdasarkan Metode 360 Derajat}

Implementasi metode penilaian menggunakan 360 derajat meliputi : a. Menentukan Penilai

Setiap pegawai koperasi dinilai prestasinya oleh beberapa pihak dari dalam dan luar organisasi. Penilai dari dalam organisasi mencakup atasan, rekan setingkat, dan bawahan (bagi posisi yang memiliki bawahan). Sementara itu, penilai dari pihak luar organisasi adalah pelanggan atau mitra kerja. Penilai kinerja para karyawan KWP meliputi beberapa pihak seperti ditunjukkan dalam Tabel 2.

b. Menentukan bobot penilaian untuk masing-masing penilai

Bobot nilai perlu dibedakan karena jenis interaksi yang berbeda antara karyawan yang dinilai dengan penilai. Pada dasarnya pembobotan ditentukan berdasarkan pertimbangan (a) frekuensi dan jenis interaksi saat bekerja, dan (b) pembobotan yang dilakukan oleh beberapa organisasi lain, baik organisasi publik maupun swasta. Pembobotan nilai untuk masing-masing penilai yang ada di KWP dirinci sebagai berikut:

1) bagi pengelola koperasi yang memiliki bawahan.
a) atasan
$40 \%$
b) bawahan
$25 \%$
c) rekan setingkat $15 \%$
d) pelanggan 20\%

2) bagi karyawan yang tidak memiliki bawahan
a) atasan
$45 \%$
b) rekan setingkat $25 \%$
c) pelanggan $30 \%$

c. Menentukan kategori atau peringkat hasil pelaksanaan penilaian 
Setelah didapatkan nilai dari pelaksanaan penilaian untuk setiap karyawan, dibuat kategori atau peringkat, yakni (a) kurang baik, (b) cukup, (c) baik, dan (d) sangat baik.

Tabel 2. Daftar Penilai Kinerja Karyawan KWP

\begin{tabular}{|c|c|c|c|c|c|}
\hline No. & $\begin{array}{c}\text { Posisi dalam } \\
\text { organisasi }\end{array}$ & Atasan & Bawahan & $\begin{array}{c}\text { Penilai } \\
\text { Rekan setingkat }\end{array}$ & Pelanggan \\
\hline 1. & Manajer & $\begin{array}{l}\text { Pengurus } \\
\text { (5 orang) }\end{array}$ & $\begin{array}{l}\text { Koord. USP; } \\
\text { Toko, } \\
\text { Fotokopi }\end{array}$ & Tidak ada & Anggota koperasi; mitra/rekanan \\
\hline 2. & Koordinator USP & Manajer & $\begin{array}{l}\text { Akuntansi; } \\
\text { Reseptionis }\end{array}$ & $\begin{array}{l}\text { Koord. Toko; } \\
\text { Koord. Fotokopi }\end{array}$ & $\begin{array}{l}\text { Anggota koperasi yang } \\
\text { menggunakan layanan unit USP }\end{array}$ \\
\hline 3. & Koordinator Toko & Manajer & Kasir 1, dan 2 & $\begin{array}{l}\text { Koord. USP; } \\
\text { Koord. Fotokopi }\end{array}$ & $\begin{array}{l}\text { Anggota koperasi yang } \\
\text { menggunakan layanan unit toko }\end{array}$ \\
\hline 4. & Koord. Fotokopi & Manajer & $\begin{array}{l}\text { Adm. } \\
\text { fotokopi }\end{array}$ & $\begin{array}{l}\text { Koord. USP; } \\
\text { Koord. Toko }\end{array}$ & $\begin{array}{l}\text { Anggota koperasi dan mahasiswa } \\
\text { yang menggunakan layanan unit } \\
\text { fotokopi }\end{array}$ \\
\hline 5. & $\begin{array}{l}\text { Sopir atau } \\
\text { penanggung jawab } \\
\text { rental mobil }\end{array}$ & Manajer & - & - & $\begin{array}{l}\text { Anggota koperasi dan mahasiswa } \\
\text { yang menggunakan layanan unit } \\
\text { toko }\end{array}$ \\
\hline 6. & Tenaga Akuntan & Manajer & - & $\begin{array}{l}\text { Kasir } 1 \& 2 \text {; Adm. } \\
\text { fotokopi; Koord. } \\
\text { USP }\end{array}$ & $\begin{array}{l}\text { Anggota koperasi pengguna } \\
\text { layanan USP }\end{array}$ \\
\hline 7. & Reseptionis & Manajer & - & $\begin{array}{l}\text { Kasir } 1 \& 2 \text {; Adm. } \\
\text { Fotokopi; Koord. } \\
\text { USP }\end{array}$ & $\begin{array}{l}\text { Anggota koperasi pengguna } \\
\text { layanan USP }\end{array}$ \\
\hline 8. & Kasir 1 & Manajer & - & $\begin{array}{l}\text { Kasir 2; Adm. } \\
\text { Fotokopi; Koord. } \\
\text { USP }\end{array}$ & $\begin{array}{l}\text { Anggota koperasi } \\
\text { layanan USP }\end{array}$ \\
\hline 9. & Merchandiser & Manajer & - & $\begin{array}{l}\text { Kasir } 1 \& 2 \text {; Adm. } \\
\text { Fotokopi; Koord. } \\
\text { USP }\end{array}$ & $\begin{array}{l}\text { Anggota koperasi } \\
\text { layanan USP }\end{array}$ \\
\hline 10. & $\begin{array}{l}\text { Administrasi } \\
\text { Fotokopi }\end{array}$ & Manajer & - & $\begin{array}{l}\text { Kasir } 1 \& 2 \text {; Adm. } \\
\text { Fotokopi; Koord. } \\
\text { USP }\end{array}$ & $\begin{array}{l}\text { Anggota koperasi } \\
\text { layanan USP }\end{array}$ \\
\hline 11. & $\begin{array}{l}\text { Administrasi } \\
\text { Umum }\end{array}$ & Manajer & - & $\begin{array}{l}\text { Kasir } 1 \& 2 \text {; Adm. } \\
\text { Fotokopi; Koord. } \\
\text { USP }\end{array}$ & $\begin{array}{l}\text { Anggota koperasi pengguna } \\
\text { layanan USP }\end{array}$ \\
\hline
\end{tabular}

Kategori ini ditentukan dengan menghitung panjang kelas $=(4-1) / 4$ $=0,75$. Dengan formula ini, didapatkan kategori nilai berikut ini.

1) $0,75-1,49$ : Kurang Baik

2) 1,50-2,24: Cukup

3) 2,25 - 2,99: Baik

4) 3 ke atas : Sangat Baik

d. Menyusun Kriteria Penilaian
Kriteria penilaian yang digunakan merupakan gabungan dari faktorfaktor dalam manajemen organisasi dan pelayanan kepada pelanggan. Faktor-faktor ini adalah keterampilan, kepribadian, kepemimpinan, aspek tangible, dan empati (Tabel 3). Setiap faktor terdiri atas beberapa indikator penilaian berikut deskripsi kriterianya. Mengingat pelaksana penilaian ada beberapa pihak, maka dilakukan penyesuaian faktor 
penilaian untuk masing-masing penilai.

e. Uji coba penggunaan intrumen penilaian

Uji coba penilaian dilaksanakan dengan cara menyebarkan formulir penilaian atau dalam bentuk Google Form. Bersamaan dengan uji coba penggunaan, lebih dulu dilakukan uji reliabilitas dan validitas pada perangkat penilaian kinerja 3600 . Pengujian validitas kualitatif dengan cara mendiskusikan komponen kompetensi pegawai yang dinilai mengacu pada kamus kompetensi disesuaikan dengan rincian tugas setiap posisi pegawai. Sementara itu, hasil pengujian kuantitatif menggunakan program SPSS menunjukkan koefisien reliabitas (Cronbach's Alpha) sebesar 0,96. Uji validitas menunjukkan bahwa 29 indikator sudah valid sehingga dapat langsung digunakan. Satu indikator yang tidak valid adalah faktor "keamanan kerja" dengan Corrected Item-Total Correlation 0,89. Berdasarkan pengalaman saat pengedaran kuesioner, muncul pertanyaan dari responden mengenai makna indikator "keamanan kerja". Misalnya, apakah indikator ini meliputi keamanan lingkungan fisik tempat kerja atau kontinuitas usaha sehingga bekerjapun kontinu. Dengan kata lain, faktor "keamanan kerja" dapat mengandung makna ganda. Cara mengatasi problem ini adalah dengan memecah satu pernyataan menjadi dua pernyataan, masing-masing ditambah penjelasannya.
Langkah uji coba yang dilakukan, dijelaskan dalam uraian berikut ini. Instrumen uji berupa formulir penilaian atau Google Form diisi oleh seluruh pengelola KWP yang berjumlah 13 orang dan 5 orang pengurus serta 63 anggota (pengguna layanan). Rincian penilai dan pihak yang dinilai adalah:

1) Manajer dinilai oleh tiga pihak, terdiri atas: atasan (seluruh anggota tim pengurus KWP; bawahan yaitu para koordinator $\mathrm{u}-$ nit; dan pelanggan.

2) Para koordinator dinilai oleh empat pihak mencakup: atasan yaitu manajer; rekan selevel yakni sesama koordinator, bawahan yaitu staf di masing-masing unit usaha, dan pelanggan dari setiap unit.

3) Setiap pegawai operasional dinilai oleh tiga pihak: atasan yaitu masing-masing koordinatornya dan manajer (khusus di KWP, desentralisasi belum sepenuhnya diberlakukan), teman selevel dan pelanggan dari masing-masing unit usaha.

Pada langkah berikutnya, dilakukan tabulasi hasil pengisian formulir yang terkumpul sampai diperoleh nilai dari masing-masing pegawai. Hasil penilaian yang dilakukan di lingkungan pengelola KWP (Tabel 4). Berdasarkan penilaian prestasi metode 3600 diketahui bahwa karyawan yang prestasinya terbaik adalah karyawan bernomor urut 3 atas nama "Il" dengan skor 3.23 dan kriteria "sangat baik". 
DIFUSI

Volume 3, No.1 Januari 2020

Tabel 3. Kriteria Penilaian

\begin{tabular}{|c|c|c|c|c|c|}
\hline \multirow[b]{2}{*}{ No. } & \multirow[b]{2}{*}{ Faktor Penilaian yang Digunakan } & \multicolumn{4}{|c|}{ Penilai } \\
\hline & & Atasan & $\begin{array}{c}\text { Rekan } \\
\text { Setingkat }\end{array}$ & Bawahan & Pelanggan \\
\hline \multicolumn{6}{|c|}{ A. Keterampilan } \\
\hline 1 & Kuantitas hasil kerja & $\checkmark$ & $\checkmark$ & $\checkmark$ & - \\
\hline 2 & Kualitas hasil kerja & $\checkmark$ & $\checkmark$ & $\checkmark$ & $\checkmark$ \\
\hline 3 & Pengetahuan akan pekerjaan & $\checkmark$ & $\checkmark$ & $\checkmark$ & $\checkmark$ \\
\hline 4 & Pemeliharaan alat kerja & $\checkmark$ & $\checkmark$ & $\checkmark$ & - \\
\hline 5 & Keamanan Kerja & $\checkmark$ & $\checkmark$ & $\checkmark$ & $\checkmark$ \\
\hline 6 & Kesadaran akan biaya & $\checkmark$ & - & - & - \\
\hline 7 & Penguasaan teknologi & $\checkmark$ & $\checkmark$ & $\checkmark$ & $\checkmark$ \\
\hline \multicolumn{6}{|c|}{ B. Kepribadian } \\
\hline 8 & Inovasi & $\checkmark$ & $\checkmark$ & $\checkmark$ & $\checkmark$ \\
\hline 9 & Motivasi kerja & $\checkmark$ & $\checkmark$ & - & - \\
\hline 10 & Kerja sama & $\checkmark$ & $\checkmark$ & $\checkmark$ & $\checkmark$ \\
\hline 11 & Keandalan & $\checkmark$ & $\checkmark$ & $\checkmark$ & $\checkmark$ \\
\hline 12 & Disiplin kerja & $\checkmark$ & $\checkmark$ & $\checkmark$ & $\checkmark$ \\
\hline 13 & Inisiatif kerja & $\checkmark$ & $\checkmark$ & - & $\checkmark$ \\
\hline \multicolumn{6}{|c|}{ C. Kepemimpinan } \\
\hline 14 & Memotivasi bawahan & $\checkmark$ & - & $\checkmark$ & - \\
\hline 15 & Daya analisis & $\checkmark$ & $\checkmark$ & - & - \\
\hline 16 & Perencanaan & $\checkmark$ & $\checkmark$ & - & - \\
\hline 17 & Pembuatan keputusan & $\checkmark$ & $\checkmark$ & $\checkmark$ & - \\
\hline 18 & Pengawasan & $\checkmark$ & $\checkmark$ & $\checkmark$ & - \\
\hline 19 & Koordinasi & $\checkmark$ & $\checkmark$ & $\checkmark$ & - \\
\hline \multicolumn{6}{|c|}{ D. Tangible } \\
\hline 20 & Penggunaan seragam & $\checkmark$ & $\checkmark$ & - & $\checkmark$ \\
\hline 21 & Penampilan & $\checkmark$ & $\checkmark$ & - & $\checkmark$ \\
\hline 22 & Daya tanggap & $\checkmark$ & $\checkmark$ & $\checkmark$ & $\checkmark$ \\
\hline 23 & Pengusaan teknologi & $\checkmark$ & $\checkmark$ & $\checkmark$ & $\checkmark$ \\
\hline \multicolumn{6}{|c|}{ E. Empati } \\
\hline 24 & Kesediaan membantu orang lain & $\checkmark$ & $\checkmark$ & - & - \\
\hline 25 & Perhatian terhadap orang lain & $\checkmark$ & $\checkmark$ & $\checkmark$ & $\checkmark$ \\
\hline 26 & $\begin{array}{l}\text { Kesungguhan dalam merespon } \\
\text { permintaan }\end{array}$ & $\checkmark$ & $\checkmark$ & $\checkmark$ & $\checkmark$ \\
\hline 27 & $\begin{array}{l}\text { Pelayanan tanpa memperhatikan status } \\
\text { sosial }\end{array}$ & $\checkmark$ & $\checkmark$ & $\checkmark$ & $\checkmark$ \\
\hline 28 & Kemampuan mengendalikan emosi & $\checkmark$ & $\checkmark$ & $\checkmark$ & $\checkmark$ \\
\hline 29 & $\begin{array}{l}\text { Memberikan pelayanan tanpa menunggu } \\
\text { lama (responsiveness) }\end{array}$ & $\checkmark$ & $\checkmark$ & $\checkmark$ & $\checkmark$ \\
\hline 30 & Mampu memahami kesulitan orang lain & $\checkmark$ & $\checkmark$ & $\checkmark$ & $\checkmark$ \\
\hline
\end{tabular}

\section{KESIMPULAN}

1. Kriteria penilaian yang digunakan dalam metode 3600 merupakan gabungan dari faktor-faktor dalam manajemen organisasi dan pelayanan kepada pelanggan. Faktor-faktor ini adalah: keterampilan, kepribadian, kepemimpinan, aspek tangible, dan empati. Setiap faktor terdiri atas beberapa indikator penilaian. Jumlah 
indikator penilaian disesuaikan dengan posisi penilai.

2. Setiap karyawan KWP dinilai oleh sejumlah pihak yang melakukan interaksi dengan karyawan yang bersangkutan sehingga dapat menilai layanan yang diberikan. Misalnya, karyawan di toko akan dinilai oleh (a) atasan langsung, (b) rekan kerja, dan (c) pelanggan.

3. Metode penilaian 3600 memberikan peluang lebih besar bagi terwujudnya objektivitas dan transparansi penilaian sehingga nilai kinerja dapat dijadikan dasar bagi pelaksanaan fungsi-fungsi manajemen SDM lainnya (misalnya pemberian insentif, promosi jabatan, identifikasi kebutuhan pelatihan).

\section{SARAN}

1. Untuk menjamin tercapainya tujuan penilaian kinerja, KWP perlu melakukan sosialisasi metode 3600 ini kepada seluruh pengurus, pengelola dan karyawan KWP. Selain itu, kepada pengurus, pengelola dan karyawan KWP ditugaskan sebagai penilai, perlu diberikan pelatihan yang memadai mengenai cara penilaian dan berbagai aspek penilaian kinerja lainnya.

2. Metode penilaian 3600 perlu dikaji ulang secara berkala untuk memastikan relevansi kriteria penilaian dengan perubahan yang terjadi dan untuk mengantipasi perubahan pada tugas-tugas yang dikerjakan oleh karyawan (yang berdampak pada faktor penilaian).

\section{UCAPAN TERIMA KASIH}

Kami ucapkan terima kasih kepada Kepala UPPM dan seluruh staf serta Ketua Jurusan Administrasi Niaga yang telah memberikan kesempatan dan kepercayaan kepada kami. Terima kasih yang tulus juga kami sampaikan kepada Pengurus dan Karyawan serta anggota/pelanggan Koperasi Warga Polban yang telah bersedia menjadi mitra dan bekerja sama secara penuh serta memberikan dukungan bagi kelancaran pelaksanaan program ini.

\section{REFERENSI}

[1] Marwansyah, Manajemen sumber daya manusia (Edisi Kedua), Bandung: Alfabeta, 2014.

[2] G. E. S. Stilling, A. S. Byrd, E. R. Mazza, dan S. M. Bergman, Still a deadly disease? Performance appraisal systems in academic libraries in the United States. College and Research Libraries, Vol. 79(3). 2018.

[3] G. Dessler, Human Resource Management (15th Ed.), Boston: Pearson. 2017.

[4] R. W. Mondy dan J. J. Martocchio, Human resource management (14th Ed.), Boston: Pearson, 2016.

[5] P. Cappelli dan M. J. Conyon, What do performance appraisals do? ILR Review, Vol. 71(1), pp. 88-116. DOI: $10.1177 / 0019793917698649$, 2017.

[6] M. Armstrong and Taylor, S. Armstrong's handbook of human resource management practice (13th Ed.), London: Kogan Page, 2014. 
DIFUSI

Volume 3, No.1 Januari 2020

[7] A. Bayo-Moriones, J. E. GaldonSanchez, dan S. Martinez-de-Morentin, Performance appraisal: dimensions and determinants, The International Journal of Human Resource Management, DOI: 10.1080/ 09585192.2018.1500387. (2019):

[8] D. Torrington, H. Laura, C. Atkinson, dan S. Taylor, Human resource management, (10th Ed.), Harlow, UK: Pearson Education Limited. 2017.

[9] R. A. Noe, J. R. Hollenbeck, B. Gerhart, P. M. Wright, Fundamentals of human resource management (6th Ed.), New York, NY: McGrawHill Education, 2016.

[10]R. L. Mathis dan J. H. Jackson, Human resource management (13th $E d$.$) , Mason, OH: Cengage Learn-$ ing, 2011.

[11]P. Balaraman, T. Gebre, G. Berhe, dan P. Kumar, Performance appraisal fundamentals, practices and challenges in public sector: case of adigrat town, ethiopia. business ethics and leadership, Vol. 2, Issue 4, pp. 18-34, 2018. 